\title{
KUALITAS PELAYANAN SERTIFIKAT TANAH HAK MILIK DI KANTOR PERTANAHAN KABUPATEN JAYAPURA
}

\section{THE SERVICE QUALITY OF CERTIFICATE LAND TITLE IN THE LAND OFFICE OF JAYAPURA REGENCY}

\author{
Hiskia C.M. Sapioper ${ }^{1}$, Marlina Flassy², dan IIham¹ \\ ${ }_{1}^{1}$ Prodi IImu Administrasi Publik, Universitas Cenderawasih \& JL. Kamp. Wolker, Waena, Kota \\ Jayapura, Papua, Indonesia \\ 2 Prodi Antropologi Sosial, FISIP Universtas Cenderawasih \& JL. Kamp. Wolker, Waena, Kota \\ Jayapura, Papua, Indonesia
}

How to cite: Sapioper,Hiskia C.M., Flassy, Marlina., \& Ilham. (2021). Kualitas Pelayanan Sertifikat Tanah Hak Milik di Kantor Pertanahan Kabupaten Jayapura. Jurnal Borneo Administrator, 17 (1), 89 110. https://doi.org/10.24258/jba.v17i1.769

\section{Article History}

Received:

25 Desember 2020

Accepted:

24 Maret 2021

\section{Keywords:}

Service Quality

Certificate

Land

\section{Kata kunci:}

Kualitas Pelayanan Sertifikat

Pertanahan

\begin{abstract}
The study aims to know and describe the quality of services and arrangements in the land certificates processing at Land Office of Jayapura Regency, Papua Province in Indonesia. This was a qualitative research by using service quality theory. This theory consists of five main dimensions namely, tangible, empathy, reliability, responsiveness, and assurance. The primary data was obtained through observation and interviews, while secondary data was obtained through library research. Data analysis was carried out through reduction and presentation, conclusions, and verification. Therefore, the results showed that service procedures were implemented according to standards, and the officers' competence were considered adequate. However, in terms of facilities and infrastructure, service standards did not meet the required expectations. Finally, the duration of the process indicated that the services provided were not responsive to the community needs.
\end{abstract}

\begin{abstract}
ABSTRAK
Kajian ini dilakukan untuk mengetahui dan mendeskripsikan kualitas pelayanan dan pengaturan pertanahan dalam pengurusan sertifikat tanah hak milik di Kantor Pertanahan Kabupaten Jayapura, Provinsi Papua. Jenis penelitian ini adalah kualitatif dengan menuang teori kualitas pelayanan yang terdiri atas lima dimensi pokok: tangible, empathy, reliability, responsiveness, assurance. Data primer diperoleh melalui pengamatan dan wawancara, data sekunder berasal dari studi kepustakaan. Analisis data dilakukan melalui reduksi data, penyajian data, penarikan kesimpulan dan verifikasi. Hasil penelitian ini menunjukkan bahwa prosedur pelayanan
\end{abstract}

\footnotetext{
* Corresponding Author

Email : ilham@fisip.uncen.ac.id
} 
telah dilaksanakan sesuai standar pelayanan, serta kompetensi petugas juga dinilai telah memadai. Kendati demikian, dari segi sarana dan prasarana belum sepenuhnya sesuai dengan standar pelayanan, lamanya proses penyelesaian pengaduan juga mengindikasikan bahwa pelayanan yang diberikan kurang memuaskan kebutuhan masyarakat selaku pengguna layanan.

\section{PENDAHULUAN}

Pemerintah telah melakukan berbagai upaya dalam rangka perbaikan kualitas pelayanan publik, baik dari segi atau aspek pengaturan, penyempurnaan kebijakan, implementasi kebijakan, maupun dari aspek peningkatan profesionalitas Sumber Daya Manusia (SDM)-nya. Kendati demikian, dewasa ini tampaknya kebijakan-kebijakan yang dilahirkan belum sepenuhnya mampu menjadi solusi dalam mengatasi berbagai permasalahan yang berkaitan dengan pemberian pelayanan publik. Fokus pelayanan dinilai belum sepenuhnya berpihak kepada masyarakat sebagai yang terlayani sehingga praktik-praktik percaloan masih marak dijumpai, diskriminasi dan budaya paternalistik masih erat mewarnai sistem pelayanan, minim perlindungan terhadap konsumen yang terkesan masih lemah, serta aparat cenderung masih menempatkan dirinya sebagai kaum untuk dilayani yang seharusnya memberikan pelayanan itu sendiri, dan persoalan-persoalan lainnya. Menurut Jufri (2019) bahwa, rendahnya kualitas pelayanan publik kerap menjadi sorotan yang ditujukan kepada birokrasi pemerintah dalam memberikan pelayanan kepada masyarakat. Berbagai tanggapan masyarakat cenderung menunjukkan adanya kemunduran terhadap sejumlah jenis pelayanan publik yang ditandai terjadinya penyimpangan dalam layanan publik tersebut, termasuk sistem dan prosedur yang berbelit-belit serta lambannya sumber daya manusia yang dimiliki juga menjadi aspek pelayanan publik yang banyak mendapatkan sorotan.

Untuk itu, diperlukan suatu upaya dalam melakukan manajemen pelayanan dengan tujuan untuk memperkuat atau menopang berbagai kebijakan-kebijakan yang telah dikeluarkan oleh pemerintah, yang berpangkal terhadap peningkatan kualitas pelayanan publik. Berangkat dari konsep New Public Service (NPS), maka faktor yang paling mendasar untuk dijadikan perhatian serius dalam penyediaan pelayanan adalah dengan mengubah mindset bahwasannya pelayanan publik yang dilakukan tidak untuk melayani pelanggan (customer), tetapi melayani masyarakat (citizen). Pelayanan publik yang mengutamakan pemenuhan kepentingan pelanggan atau customer sebagai individu untuk dilayani dengan baik sesuai hukum pasar merupakan poin utama yang dikritisi, ini cenderung mengabaikan nilai-nilai seperti kepentingan publik, demokrasi, persamaan, dan keadilan sosial dalam penyelenggaraan layanan (Tamimi, 2015). Adapun komitmen yang menjadi dasar pendekatan New Public Service agar dapat diaplikasikan dengan baik dalam institusi pemerintahan di Indonesia adalah dengan bekerja sebagai pelayanan publik atas dasar keinginan kuat untuk melayani rakyat dan menyukseskan tujuan organisasi (Ningtyas, 2017).

Salah satu bentuk pelayanan publik yang diberikan oleh aparatur birokrasi publik adalah pelayanan sertifikat tanah. Kepemilikan tanah merupakan salah satu hak yang dimiliki oleh manusia. Tanah memegang peranan penting dalam kehidupan manusia, sebagai contohnya, tanah dapat dijadikan sebagai harta atau aset untuk masa depan. Fungsi pokok tanah dalam kehidupan manusia sebagai tempat untuk melangsungkan dan melestarikan kehidupan mereka. Indonesia merupakan salah satu negara yang memiliki jumlah penduduk yang cukup besar dan padat. Sebagai negara yang sedang berkembang persoalan kependudukan kerap dialami oleh masyarakat Indonesia, salah satunya persoalan di bidang pertanahan. Masih banyak persoalanpersoalan yang kemudian menjadi keluhan masyarakat mengenai penyelenggaraan pelayanan publik dibidang pertanahan, bukan hanya masyarakat, notaris pun yang banyak mengeluhkan mengenai tumpang tindih status kepemilikan lahan (Marbun, 2014). Permasalahan pertanahan 
sebagian besar terkait pada sektor pelayanannya yang didasarkan pada data Ombudsman Republik Indonesia sejak 3 tahun terakhir dengan menunjukan bahwa secara nasional substansi pertanahan tidak pernah absen dan menempati posisi puncak sebagai substansi yang paling sering dilaporkan oleh masyarakat (Benu, 2020). Upaya dalam menyelesaikan kasus-kasus pertanahan juga diduga menjadi suatu hal penting dan harus segera dilaksanakan dan dicarikan solusinya. Dari data yang ada hingga akhir tahun 2014 kasus pertanahan nasional yang belum terselesaikan masih mencapai 50,5\% dari seluruh kasus yang masuk sebanyak 5.878 kasus (Rudiyanto et al., 2016).

Upaya pemerintah dalam melakukan perbaikan terhadap sistem pelayanan di bidang pertahanan kemudian ditandai dengan lahirnya Peraturan Kepala Badan (Perkaban) Pertanahan Nomor 1 Tahun 2010 Tentang Standar Pelayanan dan Pengaturan Pertanahan. Adanya kebijakan tersebut selanjutnya menjadi acuan dalam memberikan pelayanan kepada masyarakat terkait dengan urusan pertanahan. Kendati demikian, pada perjalanannya masih jauh dari harapan masyarakat ketika berurusan dengan pertanahan. Berbagai macam keluhan yang muncul ketika masyarakat melakukan pengurusan di kantor pertanahan, seperti terkesan berbelit-belit soal prosedur, waktu pemrosesan yang memakan waktu lama begitu juga dengan kurangnya profesionalitas petugas (Jawahir et al., 2015). Tidak bisa dimungkiri kebutuhan akan tanah semakin hari mengalami peningkatan. Konsekuensi logisnya kemudian adalah munculnya berbagai persoalan-persoalan mengenai pertanahan. Untuk menjawab berbagai tuntutan masyarakat, maka perlu adanya keterbukaan dalam pelaksanaan tugas, prosedur pembayaran yang sederhana, kepastian waktu dan biaya serta pemberian kemudahan pengurusan, kemudahan saat melayani, termasuk dengan perlindungan hak dan kepentingan masyarakat.

Berdasarkan informasi yang diperoleh dari kantor perwakilan Ombudsman Republik Indonesia Provinsi Papua mengenai persoalan-persoalan pertanahan yang menjadi aduan masyarakat sejak 2013 hingga Juli 2016 terdapat 24 kasus. Dari jumlah kasus yang dimaksudkan, beragam persoalan yang dapat diidentifikasi sebagai bentuk pelanggaran " $m a l$ administrasi". Bentuk-bentuk pelanggaran tersebut, seperti: a) Penundaan berlarut-larut, penerbitan sertifikat tanah sebanyak 15 kasus; b) Penyalahgunaan wewenang sebanyak 9 kasus. Khusus untuk Kabupaten Jayapura termasuk di dalamnya ada kedua kategori tersebut. Pada tahun 2019 tim Ombudsman Republik Indonesia melakukan gelar laporan terkait adanya tiga aduan masyarakat yang hingga pada saat itu belum memperoleh klarifikasi dari kantor ATR/BPN Kota/Kabupaten Jayapura (Kirihio, 2019).

Kondisi di atas merupakan sebagian kecil masyarakat yang mengerti dan melaporkan kasus mereka ke Perwakilan Ombudsman. Kebanyakan masyarakat merasa enggan untuk berurusan dengan alasan waktu dan biaya, serta tenaga dan pikiran, kepasrahan kemudian muncul dengan mengikuti keadaan yang ada. Faktor lain yang menyebabkan masyarakat enggan untuk mengadu karena masih adanya mindset bahwa ketika mengadu justru akan mempersulit yang bersangkutan dalam mendapatkan pelayanan ke depannya (Mardiana, 2020). Fenomena ini juga tampak dalam pelaksanaan pelayanan di Kantor Pertanahan Kabupaten Jayapura. Prosedur pelayanan, kemudahan tahapan pelayanan dari sisi kesederhanaan alur pelayanan dirasa kurang sederhana. Ketepatan dan kecepatan waktu pelayanan tidak mampu terselesaikan dalam kurung waktu yang telah ditentukan. Sehubungan pemaparan tersebut dan melihat fenomena atau permasalahan yang muncul di Kantor Pertanahan Kabupaten Jayapura, menarik perhatian penulis untuk melakukan kajian mengenai "Kualitas Pelayanan Sertifikat Tanah Tanah Hak Milik di Kantor Pertanahan Kabupaten Jayapura". Kajian ini bertujuan untuk mengetahui dan mendeskripsikan kualitas pelayanan dan pengaturan pertanahan dalam pelayanan sertifikat tanah Hak Milik di Kantor Pertanahan Kabupaten Jayapura dengan menggunakan teori kualitas pelayanan, yakni Tangibles, Empathy, Reliability, Responsiveness, dan Assurance (Tjiptono \& Chandra., 2016:137). 


\section{KERANGKA TEORI}

\section{Pelayanan Publik}

Pelayanan pada dasarnya dapat didefinisikan sebagai aktivitas seseorang, sekelompok dan atau organisasi baik langsung maupun tidak langsung untuk memenuhi kebutuhan pelanggan (Pasolong, 2017: 147). Pelayan publik merupakan upaya pencapaian tujuan secara luas untuk kepentingan publik berdasarkan kebutuhan dan kemanfaatan untuk orang lain yang dilakukan oleh pemerintah berdasarkan pada prinsip-prinsip keadilan dan kebaikan (Hayat. et al., 2018 : 219). Menurut Hidayati (2018) pelayanan publik dapat diartikan sebagai aktivitas pemberian jasa, baik oleh pemerintah maupun pihak swasta dengan cara-cara tertentu yang memerlukan kepekaan dan interpersonal dengan begitu tercipta suatu kepuasan barang dan jasa.

Tujuan utama pelayanan publik adalah untuk memenuhi kebutuhan masyarakat pengguna agar dapat memperoleh pelayanan sesuai dengan yang diharapkan dan dapat memuaskan masyarakat (Suaib, 2017). Pelayanan publik sejatinya yang diharapkan oleh masyarakat sebagai pengguna layanan dalam bentuk dan delivery yang prima dalam arti pelayanan yang memudahkan, cepat, tepat, dan aman ditandai pula dengan pemberian pelayanan yang tidak berbelit-belit, pelayanan yang well-informed, responsif, akomodatif, konsisten, dan adanya kepastian bagi dari segi waktu, biaya, hukum dan tidak dijumpai adanya pungutan yang tidak resmi (Suparman, 2017). Beberapa faktor yang kemudian dapat mempengaruhi dalam mengefektifkan pemberian pelayanan publik, seperti perbedaan dalam menginterpretasikan tugas-tugas yang harus dikerjakan serta perilaku aparat dalam menyelesaikan suatu pekerjaan, sehingga peran dan kedudukan aparat sangat penting dalam menentukan keberhasilan pada pelaksanaan tugas-tugas yang ada (Usulu, 2019).

Pelayanan publik sebagai fokus disiplin ilmu administrasi publik tetap menarik untuk dicermati karena pelayanan yang diberikan oleh aparatur pemerintah kepada publik masih dianggap belum baik atau tidak memuaskan, (Pasolong, 2017: 149). Pelaksanaan kebijakan publik belum semua instansi pemerintah secara sadar dan mampu dalam menyelenggarakan pelayanan publik secara baik kepada masyarakat (Sitorus, 2009). Permasalahan pelayanan publik sebenarnya bukan hanya terjadi di Indonesia, namun juga menjadi tema di berbagai negara yang perlu dicarikan solusi dalam pelaksanaan kebijakan pelayanan publik, karena melaksanakan pelayanan yang optimal tidaklah suatu hal yang mudah (Hayat et al ., 2018: 233). Pelaksanaan pelayanan publik harus didukung dengan sumber daya manusia yang andal dan memiliki kemampuan dalam melaksanakan pelayanan publik sehingga mesti dilakukan peningkatan kemampuan melalui pemberian pelatihan dan keterampilan dalam memberikan pelayanan publik serta harus didukung pula dengan tersedianya teknologi yang membantu pegawai (sumber daya manusia) dalam mengoptimalkan pelayanan publik (Hayat et al., 2018: 234).

\section{Kualitas Pelayanan}

Kualitas pelayanan sangatlah berpengaruh terhadap kepuasan masyarakat selaku penerima layanan sehingga apabila tingkat kualitas pelayanan semakin baik maka tingkat kepuasan masyarakat akan semakin baik pula (Jawahir et al., 2015). Pembicaraan mengenai "kualitas pelayanan" memiliki banyak definisi, Akbar dan Parvez mengartikan bahwa kualitas pelayanan merupakan pelayanan yang bertujuan untuk memenuhi kebutuhan atau harapan pelanggan (Puung \& Fudholi, 2014). Selanjutnya Kotler \& Alma mengungkapkan bahwa kualitas pelayanan merupakan suatu cara kerja yang dilakukan perusahaan dengan berusaha mengadakan perbaikan mutu yang berlangsung secara berkesinambungan terhadap proses, produk dan service dihasilkan perusahaan tersebut (Panjaitan \& Yuliati, 2016). Pada prinsipnya, definisi kualitas pelayanan berfokus pada upaya pemenuhan kebutuhan dan 
keinginan pelanggan serta ketepatan penyampaian untuk mengimbangi apa yang menjadi harapan dari pelanggan (Najmi, 2017).

Kualitas pelayanan merupakan tingkat kesempurnaan yang diharapkan dan pengendalian atas kesempurnaan tersebut dalam rangka memenuhi keinginan atau kebutuhan pelanggan, yakni ada dua faktor utama yang selanjutnya dianggap dapat mempengaruhi kualitas jasa yaitu jasa yang diharapkan dan jasa yang dipersepsikan yang berimplikasi terhadap baik-buruk kualitas jasa tergantung pada kemampuan penyedia jasa dalam memenuhi harapan pelanggan secara konsisten (Tjiptono dalam Affandi \& Zaki, 2017). Kualitas pelayanan menjadi faktor dan akar penting yang mampu memberikan kepuasan bagi pelanggannya mengenai dengan hasil perilaku dari mulut ke mulut seperti, keluhan, rekomendasi dan pertukaran atau perpindahan (Yaves et al. ; Sumarto dalam Sulistyawati \& Seminari., 2015).

Model service quality merupakan salah satu pendekatan yang banyak digunakan untuk mengetahui kualitas layanan, model ini mengacu terhadap perbandingan dua faktor utama, yaitu: persepsi atas pelayanan yang pada kenyataannya diterima oleh pelanggan (perceived service) dengan layanan yang sesungguhnya diharapkan atau diinginkan oleh pelanggan (expected service) (Parasuraman et al., 1985). Untuk dapat menilai sejauh mana mutu suatu pelayanan publik yang dilakukan atau diberikan oleh pemerintah atau perusahaan, memang tidak bisa dihindari, bahkan menjadi tolok ukur kualitas pelayanan tersebut dapat ditelaah dari kriteria dimensi-dimensi kualitas pelayanan publik.

Parasuraman et al., (1985) membagi ke dalam sepuluh dimensi untuk mengukur kualitas pelayanan, di antaranya reliability (keandalan), responsiveness (ketanggapan), competence (kompetensi), access (akses), courtesy (kesopanan), communication (komunikasi), credibility (kredibilitas), security (keamanan), understanding/knowing the customer (memahami/ mengetahui pelanggan), dan tangibles (berwujud). Secara lebih sederhana, Tjiptono \& Chandra (2016: 137) kualitas pelayanan dapat diukur melalui lima dimensi pokok, yakni 1) Bukti fisik (tangibles) yang terdiri atas indicator penampilan dari sarana prasarana, karyawan atau petugas dan fasilitas fisik lainnya; 2) Perhatian (empathy) yang terdiri dari indikator mendahulukan kepentingan pemohon, petugas melayani dengan setulus hati, ramah, sopan dan santun; 3) Keandalan (reliability) terdiri atas indikator kemampuan petugas dalam melayani segera, adanya standar pelayanan yang jelas; 4) Daya tanggap (responsiveness) yang terdiri atas indikator keinginan para petugas untuk memberikan pelayanan dengan tanggap dan membatu pemohon dalam memecahkan masalah, merespons semua keluhan pelanggan atau pemohon, petugas melakukan pelayanan dengan cepat, tepat dan cermat; 5) Jaminan (assurance) yang terdiri atas indicator petugas melayani dan menghargai setiap pelanggan, penuh kesopanan, dipercaya, termasuk mencakup tentang pengetahuan dan kompetensi petugas dalam melayani.

\section{Penelitian Terdahulu}

Guna meningkatkan kualitas pelayanan yang berkaitan dengan proses pengurusan sertifikat kepemilikan tanah, pemerintah sendiri telah melakukan pelbagai upaya dalam memberikan kemudahan kepada masyarakat, salah satunya dengan lahirnya program Layanan Rakyat untuk Sertifikat Tanah (Larasita). Adapun yang menjadi fokus dari program yang telah memadukan antara teknologi informasi dengan pelayanan petugas BPN dalam bentuk pelayanan bergerak adalah memberikan kepastian hukum dalam proses sertifikasi tanah serta memberi kemudahan layanan bagi masyarakat, sekaligus memotong mata rantai pengurusan sertifikat tanah dan meminimalisir biaya pengurusan, selain itu tujuan dari Larasita, adalah untuk menembus daerah-daerah yang sulit dijangkau sehingga masyarakat yang tinggal di daerah terpencil pun bisa dengan mudah mendapatkan pelayanan pertanahan tanpa harus menempuh jarak yang jauh dan tanpa harus mengeluarkan biaya transportasi yang besar untuk menuju Kantor Pertanahan (Saputra, 2017). 
Pada praktiknya program Larasita masih banyak menemui kendala dan dianggap belum dapat berjalan secara efektif. Hal ini sejalan dengan kajian Tianlajanu, Padmanaba \& Ayuningtyas (2015) mengenai pendaftaran tanah pertama kali melalui program Larasita Di Kantor Pertanahan Kota Bogor menunjukkan bahwa kurangnya informasi yang diperoleh masyarakat dan dukungan sumber daya manusia kurang begitu menguasai dalam pengoperasian sarana informasi dan teknologi yang telah disediakan sehingga dapat menunda pelaksanaan pelayanan pensertifikatan kepada masyarakat. Hasil kajian Nurdin (2017) juga menunjukkan bahwa implementasi program Larasita juga belum berjalan dengan baik di Kantor Pertanahan Kabupaten Donggala, hal ini jika dilihat dari faktor standar dan sasaran belum dapat menjangkau masyarakat desa yang jauh dari kota, termasuk faktor dukungan sumber daya, baik sarana dan prasarana serta, jumlah pegawai yang masih kurang, faktor komunikasi, karakteristik, kondisi sosial ekonomi dan politik maupun faktor disposisi juga belum berjalan dengan baik karena fasilitas yang disediakan belum cukup memadai.

Kemudian pembicaraan mengenai kualitas pelayanan sertifikat tanah sebagai upaya pemenuhan kebutuhan masyarakat tentang pensertifikatan tanah dan dalam penyampaian informasi tentang pertanahan juga belum dapat dikategorikan berjalan dengan baik dan efektif. Hal serupa justru terjadi pula di Ibu Kota Jakarta yang notabene lebih dekat dengan pemerintah pusat. Argumen ini didasarkan pada kajian Prasojo \& Mawar (2017) yang menunjukkan bahwa tingkat kepuasan masyarakat dalam pelayanan pembuatan sertifikat tanah di Kantor Pertanahan Kota Administrasi Jakarta Selatan dinilai masih belum tercapai. Menurut Prasojo \& Mawar (2017) lokasi Kantor Pertanahan dinilai belum layak, sarana dan prasarana lahan parkir yang sempit dan kotak saran juga belum dimanfaatkan dengan baik, begitu juga dengan target waktu penyelesaian sertifikat tanah masih lama dan belum sesuai dengan standar yang ada, sosialisasi program kerja Badan Pertanahan Nasional juga belum dilaksanakan secara optimal, rutin dan menyeluruh, kompetensi pegawai belum semua memenuhi kriteria dan dinilai belum merata sehingga butuh perbaikan dan perubahan serta peningkatan, termasuk masih ada pegawai yang kurang bersikap ramah dan peduli, sehingga keinginan masyarakat mengenai pembuatan sertifikat tanah dinilai masih belum dipenuhi dan diselesaikan secara tuntas.

Selanjutnya kajian Abidin et al. (2016) menunjukkan bahwa kualitas pelayanan dalam pembuatan sertifikat tanah di Kantor Pertanahan Kabupaten Boyolali juga dinilai masih kurang optimal, masih ditemukan petugas yang belum begitu mahir dalam melakukan pendaftaran tanah, sering ditemui kendala saat melakukan pemrosesan data, tidak seimbangnya jumlah petugas ukur dengan permintaan pengukuran, ketidakpahaman petugas akan sertifikat tanah, masih ditemukan tata cara atau alur yang tidak jelas dalam pembuatan sertifikat tanah, para petugas yang sering menunda jika ada kendala membuat waktu pelayanan menjadi sia-sia, kurang optimalnya alat pengambilan nomor antrian khusus berdampak terhadap penumpukan di bagian loket, dan kurang optimalnya penggunaan mobil Larasita dalam melakukan sosialisasi atau dengan menjemput bola di masyarakat yang berdampak terhadap rendahnya kesadaran masyarakat akan sertifikat tanah, serta waktu penyelesaian yang cukup lama dan tidak jelas membuat masyarakat menjadi enggan dalam melakukan pendaftaran tanah.

\section{METODE}

Penelitian ini menggunakan pendekatan kualitatif dengan melakukan pengamatan dan wawancara mendalam untuk mengetahui secara langsung dan membandingkan pelayanan publik di Kantor Pertanahan Kabupaten Jayapura. Moleong (2017:6) mensintesiskan dari berbagai definisi penelitian kualitatif bahwa penelitian kualitatif adalah penelitian yang bermaksud untuk memahami fenomena tentang apa yang dialami oleh subjek penelitian, misalnya perilaku, persepsi, motivasi, tindakan, secara holistic dan dengan cara deskripsi dalam bentuk kata-kata dan bahasa, pada suatu konteks khusus yang alamiah dan dengan memanfaatkan berbagai metode alamiah. Sumber data adalah para informan penelitian yang 
memahami informasi obyek penelitian, baik sebagai pelaku maupun orang lain yang memahami objek penelitian. Informan dalam penelitian ini adalah para petugas atau pegawai pada Kantor Pertanahan Kabupaten Jayapura yang terlibat langsung memberikan pelayanan sertifikat tanah serta masyarakat yang sedang melakukan pengurusan sertifikat tanahnya, termasuk yang sudah menerima sertifikat tanah.

Berhubung penelitian ini sedikit banyaknya telah memahami informasi awal yang berkaitan dengan objek penelitian, untuk mendapatkan sumber data dilakukan melalui keyinforman, yakni informan kunci yang dianggap dapat mewakili lembaganya. Data yang diambil meliputi data primer dan data sekunder. Data primer diperoleh melalui pengamatan dan wawancara langsung dengan para pengguna layanan dan para pelaksana pelayanan serta pejabat publik yang terlibat dalam proses pelayanan dimaksud sehingga yang menjadi keyinforman dalam adalah: a) Pimpinan Kantor Pertanahan Kabupaten Jayapura; b) Para Kepala Seksi dalam struktur Organisasi Kantor Pertanahan Kabupaten Jayapura; dan c) Masyarakat yang sedang melakukan pengurusan sertifikat tanah, termasuk yang telah menerima sertifikat tanahnya.

Selanjutnya, data sekunder diperoleh melalui studi kepustakaan dan laporan penyelesaian pekerjaan yang telah dilaksanakan oleh Kantor Pertanahan Kabupaten Jayapura serta peraturan perundang-undangan yang digunakan atau yang mendasari pelaksanaan pelayanan sertifikat tanah. Karakteristik penelitian kepustakaan tergolong dalam metode kualitatif sehingga ciri penelitian kualitatif harus ditransformasikan dalam konteks studi kepustakaan (Hamzah, 2020). Pengumpulan data dilakukan melalui pengamatan, dokumentasi dan wawancara. Selanjutnya dilakukan analisis data sebelum memasuki lapangan, selama di lapangan, dan setelah selesai di lapangan. Menurut Miles \& Huberman (1992) analisis data terjadi secara bersamaan; pengumpulan data, reduksi data, penyajian data, penarikan kesimpulan dan verifikasi.

Gambar 1. Komponen dan Analisis Data/model interaktif

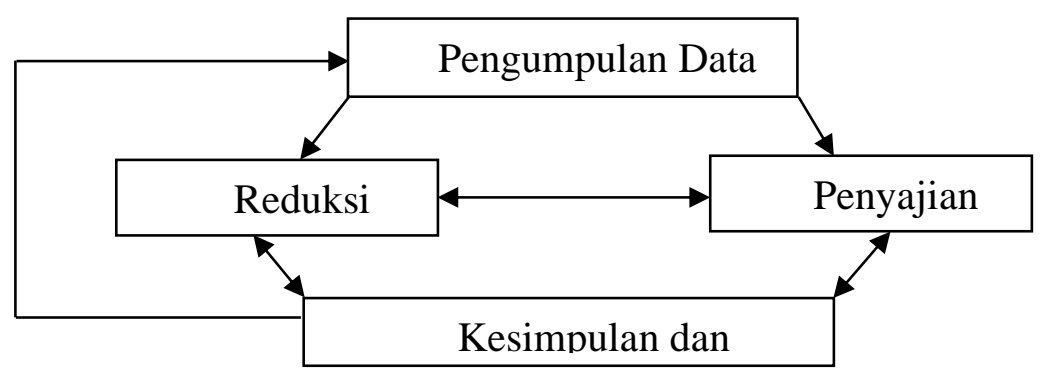

Sumber: Miles \& Huberman, 1992

\section{HASIL DAN PEMBAHASAN}

Berdasarkan hasil observasi yang dilakukan diketahui bahwa gedung Kantor Pertanahan Kabupaten Jayapura terletak di lokasi yang cukup strategis sehingga mudah dijangkau oleh masyarakat yang hendak melakukan pengurusan sertifikat tanah. Kantor Pertanahan Kabupaten Jayapura beralamatkan di Jalan Raya Sentani-Depapre, Kompleks Kantor Bupati, Sentani Kabupaten Jayapura.

Pembahasan mengenai standar pelayanan dan pengaturan pertanahan yang diberlakukan di Indonesia, termasuk pada Kantor Pertanahan Kabupaten Jayapura telah diatur dalam Peraturan Kepala Badan Pertanahan Nasional (Perkaban) Nomor 1 Tahun 2010. Untuk mengetahui dan mendeskripsikan kualitas standar pelayanan dan pengaturan pertanahan dalam pelayanan sertifikat tanah Hak Milik di Kantor Pertanahan Kabupaten Jayapura selanjutnya dapat diuraikan berdasarkan lima dimensi pokok kualitas pelayanan, yakni: Bukti fisik (tangibles), Perhatian (empathy), Kehandalan (reliability), Daya Tanggap (responsiveness), Jaminan (assurance). 
Bukti Fisik (Tangibles), distandardisasi loket pelayanan (terletak paling depan, mudah dikenal masyarakat, ada loket informasi, administrasi, pengaduan, dan keuangan, baik terpisah maupun digabung). Standarisasi desain dan tata letak ruang pelayanan (dilengkapi dengan: meja loket pelayanan, ruang tunggu, meja untuk pengisian blangko dan formulir, panel informasi manual/digital yang berisi: bagan alir pelayanan, persyaratan, biaya dan jangka waktu).

Standardisasi peralatan pelayanan (peralatan teknologi/komputerisasi, penyimpanan arsip, perlengkapan keamanan, alat pemadam kebakaran dan kotak pengaduan), termasuk sarana dan prasarana berupa gedung dan segala fasilitas yang dimiliki dalam menunjang kelancaran proses pelayanan sertifikat tanah di Kantor Pertanahan Kabupaten Jayapura. Pembicaraan mengenai standarisasi loket pelayanan. Kepala Seksi Sengketa Konflik dan Perkara pada Kantor Pertanahan Kabupaten Jayapura berinisial MS, yang mengungkapkan bahwa:

"Standarisasi loket pelayanan, sarana dan prasarana yang ada di kantor pertanahan Kabupaten Jayapura ini, belum memadai dan masih jauh dari harapkan masyarakat, belum memadai sebagai kantor pelayanan publik. Disamping kantornya sempit (seperti yang bapak lihat sendiri) tidak mungkin juga kantor ini bisa dipetakpetakkan dan dibuatkan untuk loket pelayanan kepada masyarakat karena situasi kantor yang memang tidak memadai", (wawancara tanggal 8/10/2019).

Masyarakat yang hendak melakukan pengurusan sertifikat tanahnya akan langsung dihadapkan dengan penilaian fasilitas yang ada, kesigapan aparat yang melayani serta kebersihan dan kenyamanan kantor. Kenyamanan masyarakat akan langsung terasa sehingga perlu dilakukan penataan ruang tunggu yang lebih baik. Selain itu, penataan atau pengadaan papan informasi/brosur/leaflet yang dipajang agar bisa dilihat oleh masyarakat dan sekaligus dapat membantu dan mempermudah masyarakat dalam pengurusan proses sertifikat tanah mereka. Kantor Pertanahan Kabupaten Jayapura mulai menyadari bahwa betapa pentingnya menata dan menyesuaikan standarisasi terhadap sarana dan prasarana yang mereka miliki guna memberikan pelayanan yang terbaik bagi masyarakat yang mengurus sertifikat tanah mereka. Standarisasi loket pelayanan, desain tata letak ruang pelayanan. Peralatan pelayanan yang penulis amati sedikit demi sedikit telah terpenuhi walaupun loket pelayanan, dan loket-loket lain berada dalam satu ruangan yang dipisahkan oleh meja yang satu dengan meja yang lain. Setidaknya ini sudah menunjukan bahwa kantor tersebut sudah mulai menata dan mengikuti standar yang ada.

Secara umum sarana dan prasarana merupakan alat penunjang yang menjadi salah faktor penentu keberhasilan pelayanan public yang dilakukan. Berdasarkan informasi atau pernyataan dari informan baik yang disampaikan oleh aparatur kantor Pertanahan Kabupaten Jayapura maupun masyarakat yang dilayani dalam proses pengurusan pelayanan sertifikat tanah ketika dilihat dari dimensi tangibles (bukti fisik) mengenai dukungan sarana dan prasarana yang ada belum sepenuhnya memberikan harapan sesuai dengan standar pelayanan yang telah dipersyaratkan. Moenir (1992) mengemukakan bahwa sarana adalah segala bentuk peralatan dan perlengkapan kerja, serta dukungan fasilitas yang berfungsi sebagai alat utama yang dapat menopang penyelesaian suatu pekerjaan, termasuk dalam rangka kepentingan yang berkaitan dengan organisasi kerja. Definisi sarana dan prasarana sebagaimana diajukan oleh Moenir, memberikan gambaran bahwa dukungan sarana dan prasarana baik berupa peralatan pembantu maupun peralatan utama, keduanya memiliki fungsi dalam mencapai tujuan yang dikehendaki.

Perhatian (Emphaty), kemudahan memahami masalah atau persoalan yang sedang dihadapi pemohon atau masyarakat yang dilayani dan bertindak demi kepentingan masyarakat, memberikan perhatian personal kepada masyarakat, serta memiliki jam operasi yang nyaman. Bila dikaitkan dengan standar pelayanan dan pengaturan pertanahan sesuai dengan Perkaban 
Nomor 1 Tahun 2010, indikator ini berhubungan dengan respons pengaduan pelayanan. Hal ini berhubungan dengan petugas pelayanan dalam merespons permintaan masyarakat terkait dengan saran dan keluhan yang mereka sampaikan. Adapun Proses pengaduan masyarakat terkait dengan pelayanan sertifikat tanah yang mereka terima dapat digambarkan sebagai berikut:

Tabel 1. Dasar hukum, biaya, dan Waktu Penyelesaian dalam proses pengaduan

\begin{tabular}{|c|c|c|c|c|}
\hline Dasar Hukum & Persyaratan & Biaya & Waktu & Ket \\
\hline $\begin{array}{l}\text { Undang-Undang Nomor } \\
5 \text { Tahun } 1960\end{array}$ & $\begin{array}{l}\text { Pengaduan } \\
\text { secara tertulis } \\
\text { baik yang }\end{array}$ & $\mathrm{Rp} 0,00$ & Lima hari & $\begin{array}{l}\text { Jika penyelesaian atas } \\
\text { pengaduan } \\
\text { membutuhkan waktu }\end{array}$ \\
\hline $\begin{array}{l}\text { Undang-undang Nomor } \\
25 \text { Tahun } 2009\end{array}$ & $\begin{array}{l}\text { disampaikan } \\
\text { melalui loket, } \\
\text { kotak } \\
\text { pengaduan, } \\
\text { website }\end{array}$ & & & $\begin{array}{l}\text { lebih dari lima hari, } \\
\text { maka unit kerja terkait, } \\
\text { berkewajiban } \\
\text { memberikan } \\
\text { tanggapan atau } \\
\text { jawaban terhadap } \\
\text { pengajuan yang } \\
\text { disampaikan }\end{array}$ \\
\hline
\end{tabular}

Sumber: Diadaptasikan dari Perkaban Nomor 1 Tahun 2010

Pada tabel tersebut, dengan mengacu pada Undang-undang Nomor 5 Tahun 1960 memuat tentang Peraturan Dasar Pokok-Pokok Agraria yang menjamin adanya kepastian hukum yang diberikan Pemerintah terhadap warga negara untuk memperoleh hak atas tanahnya di seluruh wilayah Indonesia. Selanjutnya Undang-undang Nomor 25 Tahun 2009 tentang Pelayanan Publik, setiap bentuk kebijakan yang kaitannya dengan pelayanan publik yang dikeluarkan oleh pemerintah mesti memiliki dasar hukum yang menandakan bahwa pelayanan publik yang diberikan sah menurut hukum dan perundangan.

Pengelolaan pengaduan merupakan suatu proses penanganan pengaduan yang dilakukan yang dimulai dengan menyeleksi, menelaah, dan mengklasifikasi hingga pada tahap kepastian penyelesaian pengaduan tersebut. Adapun persyaratan pengaduan dilakukan tertulis, baik yang disampaikan melalui loket, kotak pengaduan, maupun pengaduan yang disampaikan melalui website. Pengaduan ini tidak dipungut biaya apapun, serta jangka waktu pengaduan yang diajukan sesuai dengan ketentuan adalah lima hari kerja sudah harus mendapat respons atau tanggapan dari unit kerja yang bersangkutan terhadap pengaduan yang disampaikan oleh masyarakat atau warga yang mengurus sertifikat tanahnya di Kantor Pertanahan Kabupaten Jayapura.

Dalam merespons pengaduan yang disampaikan masyarakat terhadap permasalahan menyangkut proses pengurusan sertifikat tanah pada kantor pertanahan Kabupaten Jayapura, seorang informan berinisial AD memberikan pernyataan bahwa:

\section{"Proses pengaduan dimulai dari surat yang masuk ke kantor, naik ke kepala kantor kemudian didisposisikan ke seksi masing-masing bidang pengaduannya" (wawancara tanggal 4/11/2019).}

Selanjutnya mengenai pengelolaan pengaduan dan waktu penyelesain pengaduan masyarakat atas permasalahan yang dihadapi dalam melakukan pengurusan sertifikat tanah pada Kantor Pertanahan Kabupaten Jayapura. Informan lainnya yang berinisial BA, menyampaikan bahwa:

"Telah sesuai karena pengaduan masyarakat tentang pelayanan telah difasilitasi oleh setiap kantor pertanahan baik melalui loket maupun media lainnya. Untuk 
waktu penyelesaian mulai dari proses pengaduan hingga penyampaian hasil tergantung dari jenis pengaduan dan permasalahannya sehingga bisa memakan waktu kurang atau bahkan lebih dari lima hari" (Wawancara tanggal 4/11/2019)

Pernyataan aparat Kantor Pertanahan Kabupaten Jayapura menunjukkan bahwa mekanisme proses pengaduan dari masyarakat atau surat masuk telah dilaksanakan sesuai dengan mekanisme yang sudah diatur. Surat masuk ataupun pengaduan yang mekanismenya melalui kepala kantor kemudian didisposisikan kepada masing-masing seksi terkait dengan bidang ataupun masalah yang ditangani. Sejak dikeluarkannya Perkaban Nomor 2 tahun 2010 tentang Penanganan Pengaduan Masyarakat, hingga sekarang masih ditemukan beberapa pengaduan yang muncul dari masyarakat. Hal ini juga terjadi pada sistem penanganan pengaduan masyarakat yang ada di Kantor Pertanahan Kabupaten Jayapura. Penanganan masalah pengaduan tidak sejalan dengan harapan masyarakat, kendati telah diatur dalam peraturan pemerintah akan tetapi penanganan pengaduan belum dilaksanakan secara maksimal.

Beberapa pengaduan yang disampaikan oleh masyarakat mengindikasikan bahwa Kantor Pertanahan Kabupaten Jayapura belum memberikan pelayanan secara terbuka, terbukti masih banyak masyarakat yang menanyakan prosedur pelayanan yang menurut mereka masih belum jelas. Seperti halnya disampaikan salah seorang masyarakat yang melakukan pengurusan sertifikat tanah di Kantor Pertanahan Kabupaten Jayapura berinisial RB yang menuturkan bahwa :

"Proses pemberitahuan kepada pengadu memang rata-rata 5 (lima) hari kerja, tetapi proses penyelesaian masalah yang diadukan kadang memakan waktu yang cukup lama, disebabkan banyak pengaduan dan sengketa tanah yang juga antri untuk dilakukan penyelesaian," (Wawancara tanggal 7/11/2019)

Seorang informan lainnya yang juga sedang melakukan pengurusan sertifikat tanah di Kantor Pertanahan Kabupaten Jayapura berinisial JT mengungkapkan bahwa:

"Kadang direspon kadang juga tidak. Karena saya juga mengalami komplain kepemilikan tanah dari pihak-pihak lain yang merasa masih memiliki tanah yang telah saya beli, sehingga petugas pengukur tanah beberapa kali kembali melakukan pengukuran dan meminta saya untuk mengecek kembali status kepemilikan tanah", (Wawancara tanggal 7/11/2019).

Penanganan pengaduan tidak dapat direspons dengan baik oleh aparat kantor Pertanahan Kabupaten Jayapura, bahkan terkesan jawaban ataupun respons yang diberikan kepada masyarakat bisa memakan waktu lebih lama. Hal ini kemudian diperkuat dengan pernyataan yang dikemukakan oleh seorang informan berinisial HS, yang menyebutkan bahwa:

"Saya sudah datang mengadu kepada pihak pertanahan selama 5 hari kerja, saya dilayani tetapi saya harus menunggu bisa 10 hari atau 1 bulan, pelayanan yang lama membuat saya mengeluh dan menganggap bahwa pengaduan saya diabaikan dan tidak diproses", (Wawancara tanggal 7/11/2019)

Pengelolaan pengaduan pada Kantor Pertanahan Kabupaten Jayapura masih belum transparan dalam memberikan informasi terkait pelayanan yang ada disana. Kemudian lamanya proses pengaduan masyarakat mengindikasikan bahwa pelayanan pada Kantor Pertanahan Kabupaten Jayapura kurang tanggap terhadap kebutuhan masyarakatnya sebagai 
pengguna layanan. Profesionalisme birokrasi yang belum mampu memahami serta memenuhi kebutuhan masyarakat dapat mempengaruhi akuntabilitas sebagai bentuk pertanggungjawaban pemerintah yang notabene memiliki tugas memberikan pelayanan yang baik kepada masyarakat selaku pengguna layanan. Agar terselenggara penanganan pengaduan yang efektif serta mampu memberikan kontribusi dalam mewujudkan pemerintah yang baik, maka diperlukan penanganan pengaduan dengan mengadopsi prinsip-prinsip good governance, yaitu transparansi, responsivitas dan akuntabilitas. Senada dengan pendapat Hughes yang mengatakan bahwa pada era reformasi proses interaksi antara pemerintah dengan masyarakat, integritas pemerintah kini lebih dinilai dari segi accountability, responsiveness, dan transparency (Keban, 2008; Styawan, 2012). Penanganan pengaduan hendaknya dilakukan secara transparan, kemudian direspon dengan baik, sehingga mampu mewujudkan akuntabilitas atas pengaduan yang ada dengan mempertanggungjawabkan dan melakukan penyelesaian terhadap pengaduan masyarakat sebagai wujud pemberian pelayanan publik. Hal ini memberikan kesempatan kepada masyarakat untuk bisa memantau kinerja dari lembaga pemerintahan dalam memberikan pelayanan, khususnya penanganan pengaduan yang mereka sampaikan terkait dengan proses pengurusan sertifikat tanah. Perlunya prinsip transparansi, responsivitas, dan akuntabilitas tersebut kemudian diperjelas oleh Mardiasmo, bahwa dalam memberikan layanan kepada masyarakat sehingga dituntut agar lebih responsif. Salah satu mekanisme yang dapat dilaksanakan daerah agar lebih responsif, transparan, dan akuntabel serta selanjutnya dapat mewujudkan good governance adalah dengan mendengarkan apa yang telah menjadi aspirasi dari masyarakat termasuk membangun kerjasama memberdayakan masyarakat (Styawan, 2012).

Kehandalan (Reliability), Kemampuan memberikan pelayanan yang telah dijanjikan dengan segera, akurat, dan memuaskan terhadap proses pelayanan sertifikat tanah baik pada Kantor Pertanahan Kabupaten Jayapura. Apabila dikaitkan dengan Standar Pelayanan dan Pengaturan Pertanahan berdasarkan Perkaban Nomor 1 Tahun 2010 mengenai dengan waktu penyelesaian serta biaya. Waktu penyelesaian dalam hal ini adalah jangka waktu penyelesaian pelayanan pertanahan terhitung sejak penerimaan berkas lengkap dan telah lunas pembayaran biaya yang ditetapkan. Jangka waktu sebagaimana yang dimaksud tidak ditujukan atau tidak berlaku terhadap permohonan yang dalam prosesnya tanah tersebut sedang bersengketa, konflik, perkara, atau masalah hukum lainnya, sehingga kemudian berkasnya dapat dikembalikan kepada pemohon. Kemudian untuk biaya penyelesaian yang dimaksudkan adanya biaya pelayananan yang ditujukan kepada pemohon sesuai dengan peraturan perundang-undangan tentang jenis dan tarif atas jenis penerimaan negara bukan pajak yang berlaku pada Badan Pertanahan Nasional Republik Indonesia. Adapun jangka waktu penyelesaian serta biaya pelayanan sertifikat tanah berdasarkan Perkaban Nomor 1 Tahun 2010, yang juga telah menjadi acuan dan standar pelayanan pertanahan yang berlaku di Kantor Pertanahan Kabupaten Jayapura, dapat dilihat pada tabel berikut ini:

Setelah semua persyaratan dilengkapi selanjutnya biaya pengurusan sebagaimana yang telah diatur dalam PP Nomor 13. Tahun 2010 Tentang Jenis dan Tarif atas Jenis Penerimaan Negara Bukan Pajak yang berlaku pada Badan Pertanahan Nasional Republik Indonesia dimana diatur perorangan/per bidang Rp50.000,00 (diluar biaya pengukuran). Selanjutnya setelah pengukuran dilaksanakan sampaikan dengan penyerahan sertifikat tanah kepada pemohon, yakni 98 (sembilan puluh delapan) hari. Selanjutnya mengenai jangka waktu penyelesaian pelayanan sertifikat tanah sesuai dengan Perkaban Nomor 1 Tahun 2010 juga merupakan standar pelayanan pertanahan yang berlaku pada Kantor Pertanahan Kabupaten Jayapura sebagaimana yang telah ditetapkan seperti pada tabel diatas, yakni 98 (sembilan Puluh Delapan) hari kerja. Kendati demikian, informasi yang disampaikan oleh aparatur kantor Pertanahan Kabupaten Jayapura maupun masyarakat yang dilayani selaku pemohon dalam proses pengurusan pelayanan sertifikat tanah, dari segi waktu penyelesaian maupun 
biaya yang sudah ditetapkan belum sepenuhnya terlaksana dengan baik sesuai dengan standar pelayanan yang dipersyaratkan.

Tabel 2. Persyaratan, Biaya, dan Waktu Penyelesaian Sertifikat Tanah

\begin{tabular}{|c|c|c|}
\hline Persyaratan & Biaya & Waktu \\
\hline $\begin{array}{l}\text { 1. Formulir permohonan yang sudah diisi } \\
\text { dan ditandatangani pemohon atau } \\
\text { kuasanya di atas materai cukup }\end{array}$ & $\begin{array}{l}\text { PP. No.13. Tahun } \\
\text { 2010, Tentang Jenis } \\
\text { dan Tarif atas Jenis }\end{array}$ & $\begin{array}{l}98 \text { (sembilan } \\
\text { puluh delapan) } \\
\text { hari }\end{array}$ \\
\hline 2. Surat Kuasa apabila dikuasakan & Penerimaan Negara & \\
\hline $\begin{array}{l}\text { 3. Fotocopy identitas } 1 \mathrm{KTP}, \mathrm{KK} \text { ) pemohon } \\
\text { dan kuasa apabila dikuasakan, yang telah } \\
\text { dicocokkan dengan aslinya oleh petugas } \\
\text { loket }\end{array}$ & $\begin{array}{l}\text { Bukan Pajak yang } \\
\text { berlaku pada BPN.RI } \\
\text { Perorangan/per bidang } \\
\text { Rp50.000,00 }\end{array}$ & \\
\hline $\begin{array}{l}\text { 4. Bukti pemilikan tanah/alas hak milik } \\
\text { adat/bekas milik adat }\end{array}$ & & \\
\hline $\begin{array}{l}\text { 5. Foto copy SPPT PBB Tahun berjalan } \\
\text { yang telah dicocokkan dengan aslinya } \\
\text { oleh petugas loket dan penyerahan bukti } \\
\text { SSB BPHTB) }\end{array}$ & & \\
\hline $\begin{array}{l}\text { 6. Melampirkan bukti SSP/PPh sesuai } \\
\text { dengan ketentuan }\end{array}$ & & \\
\hline
\end{tabular}

Sumber: Perkaban Nomor 1 Tahun 2010

Berikut penjelasan dari salah seorang informan yang bertugas pada Kantor Pertanahan Kabupaten Jayapura berinisial MA, menyebutkan bahwa:

"Idealnya pembuatan sertifikat tanah untuk pendaftaran tanah pertama kali memang 98 hari, namun pada prakteknya sering terjadi permasalahan pada saat proses berjalan. Hal tersebut biasanya sering terjadi pada tahap pengumuman karena memang dalam peraturan disediakan fasilitas untuk mengajukan keberatan atas proses pembuatan sertifikat terhadap tanah yang didaftarkan tersebut, (wawancara tanggal 13/10/2019).

Pengurusan sertifikat tanah di Papua juga biasanya dihadapkan dengan persoalan hak ulayat. Permasalahan pelepasan tanah adat atau tanah ulayat tersebut akan berdampak terhadap lamanya waktu penyelesaian sertifikat tanah. Hal ini kemudian dipertegas oleh seorang informan berinisial IS, yang menuturkan bahwa :

"Untuk waktu penyelesaian sertifikat tanah bisa memakan lebih waktunya karena status kepemilikan tanah adat di Papua, berbeda dengan provinsi lain" (wawancara tanggal 13/10/2019).

Selanjutnya mengenai besaran biaya yang harus dibayarkan dalam penyelesaian sertifikat tanah, khususnya pendaftaran tanah pertama kali sebagaimana yang dikemukakan oleh informan kunci berinisial MA, menyampaikan bahwa:

"Untuk biaya PNBP khususnya pendaftaran tanah pertama kali, ada 3 item PNBP yang harus dibayarkan pendaftaran (Rp50.000,00), pengukuran, yang besarnya tergantung pada luas tanah yang dimohon dan penggunaan tanah (pertanian/non 
pertanian), Selain biaya PNBP tersebut kepada pemohon juga dibebankan biaya operasional" (Wawancara 15/10/2019)

Untuk Biaya pendaftaran tanah pertama kali dengan tarif Rp50.000,00 merupakan biaya sudah diatur dalam PP. No.13 Tahun 2010 tentang Penerimaan Negara Bukan Pajak (PNBP) yang berlaku pada Badan Pertanahan Nasional Republik. Seorang informan lainnya berinisial MB, mengungkapkan bahwa:
"Pembayaran biaya pengukuran dan pembuatan peta berdasarkan skala perbandingan telah dilaksanakan sesuai ketentuan yang berlaku. Namun untuk biaya akomodasi pengukuran bervariasi ditanggung pemohon sesuai letak lokasi tanah yang dimohon" (wawancara tanggal 15/10/2019).

Berdasarkan pernyataan yang telah dikemukakan oleh aparat pelayanan di atas selanjutnya pertanyaan yang sama ditujukan kepada masyarakat atau warga Kabupaten Jayapura. Hal ini dimaksudkan untuk menanggapi dan sekaligus menilai sejauh mana waktu dan biaya penyelesaian dari proses pelayanan pengurusan sertifikat tanah yang mereka hadapi sesuai dengan pengalaman mereka pada waktu mengurus sertifikat tanah. Salah seorang informan berinisial HM, yang beralamatkan di Hawai Sentani menuturkan pendapatnya bahwa:

\begin{abstract}
"Menurut saya apa yang telah diatur dalam Perkaban Nomor 1 Tahun 2010, dalam implementasinya di lapangan bisa lebih dari 98 hari bahkan bisa sampai tahunan (1-3 tahun), terkadang saya sudah bosan bolak-balik kantor pertanahan ini untuk mengecek perkembangan penyelesaian/sertifikat yang sudah saya ajukan petugas selalu menjawab sabar terus" (wawancara tanggal 15/10/2019).
\end{abstract}

Sertifikat sebagai bukti kepemilikan yang sah dan mempunyai kekuatan hukum tentunya sangat diharapkan segera bisa dimiliki oleh masyarakat yang memiliki tanah Apabila proses penerbitan sertifikat dengan cepat dalam hal ini sesuai jangka waktu yang ditentukan, tentunya sangat membahagiakan bagi masyarakat. Mengingat sertifikat tanah mempunyai nilai ekonomis yang relatif berharga dan paling mudah dijadikan agunan. Berdasarkan hasil pengamatan penulis melihat masih munculnya faktor mental aparat yang sering menunda pekerjaan. Kondisi ini menyebabkan masyarakat seperti trauma terhadap perlakuan pihak aparat Kantor Pertanahan, apalagi masyarakat sering dijanjikan untuk pengambilan sertifikat, namun ketika didatangi ternyata belum diterbitkan. Hal seperti ini kerap terjadi berulang kali hingga berlarut-larut. Seperti halnya pernyataan informan berinisial JT, seorang Pensiunan PNS yang beralamatkan di Yahim Sentani mengungkapkan bahwa :

"Tidak sesuai dengan waktu 98 hari kerja karena saya setelah memasukkan semua dokumen yang dipersyaratkan sekitar tahun 2011, saya baru menerima sertifikat tanah saya pada tahun 2014. Seingat saya pada tahun 2012, saya cek kembali lagi sertifikat tanah saya, ada pergantian kepala Kantor Pertanahan yang baru, Kepala Kantor yang baru tidak mau menandatangani dan meminta untuk mengajukan persyaratan baru dan dilakukan pengukuran ulang kembali. Yah itu terpaksa kami sesuaikan dengan mereka, karena mereka yang atur seperti itu jadi" (Wawancara tanggal 18/10/2019).

Kemudian mengenai biaya pendaftaran pertama kali sebagaimana telah diatur dalam PP Nomor 13 Tahun 2010. Salah seorang informas berinisial HM menyampaikan bahwa : 
"Biaya pendaftaran pertama kali: Kadang tidak sesuai dengan ketentuan PP No.13/2010 biayanya Rp50.000,00 tanah itu mahal dan bervariasi harganya disebabkan karena letak strategis dari tanah tersebut. Saya sendiri membeli tanah seharga Rp200.000,00/m2. Ada tanah yang dijual mahal karena dianggap prospeknya ke depan menjanjikan. Biaya pengukuran dan peta: Kadang ada yang sesuai biaya pengukuran peta Rp250.000,00 ada juga yang tergantung pada luas dan lebarnya area tanah tersebut, bisa lebih dari Rp250.000,00 " (Wawancara tanggal 18/10/2019).

Informasi yang disampaikan oleh aparatur kantor Pertanahan Kabupaten Jayapura maupun masyarakat yang dilayani dalam proses pengurusan pelayanan sertifikat tanah dari segi waktu penyelesaian sertifikat tanah dan biaya yang sudah ditetapkan belum sepenuhnya terlaksana dengan baik sesuai dengan standar pelayanan yang dipersyaratkan. Kehandalan merupakan aspek pertama dalam mengukur kualitas pelayanan publik yang erat kaitannya dengan dengan kemampuan sumber daya manusia dalam melakukan pelayanan yang tentunya sesuai dengan ketentuan atau standar yang berlaku. Aspek keandalan ini, dapat diukur melalui lima indikator, yaitu kesiapan aparat di tempat kerja, kecepatan dalam proses pelayanan, kemampuan untuk memenuhi kebutuhan pelanggan, ketepatan waktu dalam memberikan pelayanan, serta adanya kesesuaian layanan dengan ketentuan yang berlaku. Kelima indikator mesti terpenuhi dalam memberikan pelayanan, sehingga keterampilan kerja menjadi bagian tak terpisahkan yang mesti dimiliki petugas pelayanan. Menurut Najmi (2017) keterampilan kerja dapat diartikan sebagai hasil yang dapat dicapai seseorang menurut ukuran yang berlaku untuk pekerjaan atau tugas yang bersangkutan.

Daya tanggap (Responsiveness), prosedur pelayanan publik mesti didesain dengan sederhana dengan tujuan agar pelayanan yang diberikan tidak terkesan berbelit-belit, lebih mudah untuk dipahami dan dilaksanakan, serta adanya bagan alir (flowchart) yang terpampang dalam ruangan pelayanan yang berfungsi sebagai alat bantu komunikasi Bagan alir (flowchart) adalah bagan yang menunjukkan alir di dalam program atau prosedur di dalam sistem secara logika, yang digunakan terutama untuk alat bantu komunikasi dan untuk dokumentasi (Anggiawan et al., 2018). Bagan alir ini sangat penting dalam pelaksanaan dan penyelenggaraan pelayanan public, sebab memiliki beberapa fungsi, diantaranya: a) berfungsi sebagai petunjuk kerja bagi petugas pelayanan; b) sebagai sumber informasi bagi masyarakat atau pemohon yang akan dilayani; c) sebagai sarana publikasi secara terbuka mengenai prosedur pelayanan kepada penerima masyarakat atau pemohon yang dilayani; d) pendorong terciptanya sistem dan mekanisme kerja sehingga lebih efektif dan efisien; dan e) berfungsi sebagai pengendali atau alat kontrol bagi masyarakat begitu juga aparat pengawasan pada saat melakukan penilaian atau pengawasan.

Prosedur Pelayanan yang dimaksud disini adalah tahapan proses pelayanan untuk masingmasing jenis kegiatan sebagaimana bagan alir yang tercantum dalam peraturan ini. Selanjutnya diuraikan pelaksanaan prosedur pelayanan sesuai dengan standar pelayanan sebagaimana dipersyaratkan dalam Perkaban Nomor 1 Tahun 2010 yang juga berlaku baik pada Kantor Pertanahan Kabupaten Jayapura, sebagaimana terlihat pada gambar 2. 
Gambar 2. Alur pengurusan sertifikat tanah

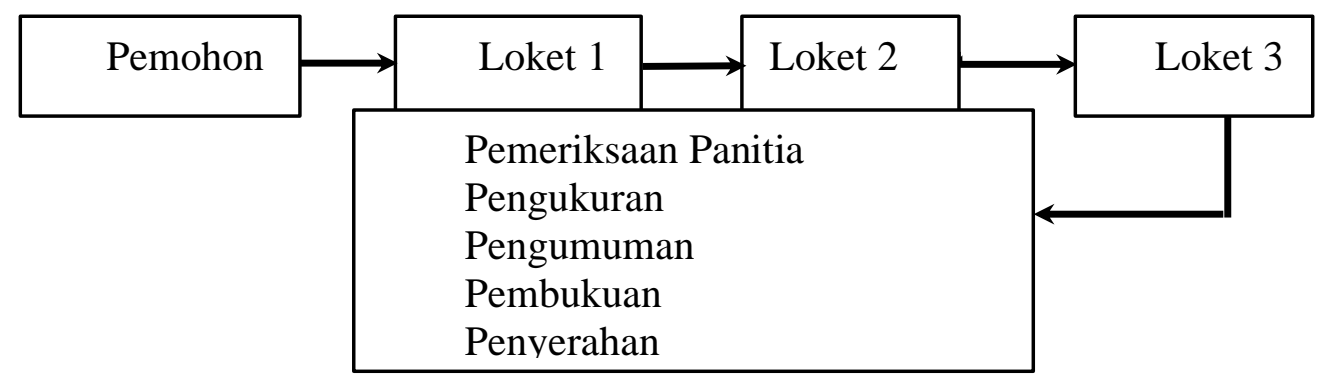

Sumber: diadaptasikan dari Perkaban Nomor 1 Tahun 2010

Untuk menelusuri apakah implementasi dari Perkaban Nomor 1 Tahun 2010 juga telah dilaksanakan di Kantor Pertanahan Kabupaten Jayapura. Apakah Kantor Pertanahan Kabupaten Jayapura ini dalam memberikan pelayanan sertifikat tanah sudah berdasarkan flowchart atau alur loket: Loket penerimaan dan pemeriksaan dokumen, pembayaran, pengukuran dan seterusnya sampai pada penyerahan sertifikat tanah. Seorang informan berinisial AD menyampaikan bahwa:

"Sudah sesuai dengan Perkaban Nomor 1 Tahun 2010, baik dokumen fisik maupun aplikasi semua proses (khususnya pendaftaran tanah pertama kali) prosedurnya telah dilaksanakan sesuai dengan peraturan yang berlaku. Setiap permohonan baru akan diproses apabila semua kelengkapan dokumen telah terpenuhi. Dokumendokumen tersebut dibutuhkan di setiap tahap penerbitan sertifikat mulai dari pemeriksaan dokumen, proses pengukuran, pemeriksaan hingga penyerahan dokumen sehingga saling terkait. Kantor pertanahan ini juga menerapkan tertib administrasi agar semua dokumen terjaga dengan baik" (wawancara tanggal 21/10/2019).

Setiap permohonan baru akan diproses apabila semua kelengkapan dokumen yang telah dipersyaratkan telah terpenuhi saat melakukan pengurusan sertifikat tanah di Kantor Pertanahan Kabupaten Jayapura. Hal Senada juga disampaikan informan lainnya berinisial IS, yang menuturkan bahwa:

"Iya, saya kira kalau semua persyaratan yang sudah dinyatakan lengkap sehingga segera diproses menurut standar pelayanan yang dimaksud. Bagi masyarakat yang telah melengkapi persyaratannya dengan lengkap dilayani sampai ke loket pelayanan penyerahan, jika di tengah-tengah proses pensertifikatan tidak ada gugatan atau keberatan dari pihak lain maka kami akan kembalikan" (wawancara tanggal 21/10/2019).

Untuk mendapatkan pelayanan sertifikat tanah masyarakat atau pemohon penting untuk memperhatikan dan mengetahui mekanisme atau prosedur pelayanan umum di kantor pertanahan setempat, seperti pada gambar 2 yang telah disajikan di atas. Proses dan pentahapan tersebut diatas adalah mekanisme yang telah diatur oleh Peraturan Kepala Badan Pertanahan Nasional Republik Indonesia Nomor 1 Tahun 2010, sekaligus menjadi Standar Pelayanan dan Pengaturan Pertanahan yang diberlakukan secara nasional termasuk di Kantor pertanahan Kabupaten Jayapura.

Khususnya di Papua, mesti berhati-hati ketika hendak melakukan transaksi jual-beli tanah. Sertifikat bukan acuan utama! Mindset masyarakat lokal belum sampai pada pengakuan sertifikat sebagai hak terkuat. Hukum adat (hak ulayat) masih sangat kental. Tapi, harus 
diperhatikan juga bahwa hak ulayat di sana memiliki logika hukum yang berbeda dengan daerah lainnya. Disaat membeli tanah dari orang lain (masyarakat adat) harus ditelusuri dan didasari dengan sikap penuh kehati-hatian: dari mana asal-usulnya, bagaimana sejarah pelepasan tanahnya, bagaimana pembayaran uang ganti ruginya, serta kwitansi-kwitansi pembayarannya. Di tanah Papua, hingga saat ini hukum adat masih sangat dominan. Hak ulayat menjadi permasalahan dalam penegakan hukum agraria nasional. Bahkan sertifikat hak atas tanah yang telah diterbitkan Badan Pertanahan Nasional (BPN) terkadang dianggap tidak sah. Sertifikat Hak Milik (SHM) atau Sertifikat Hak Guna Bangunan (HGB) yang notabene adalah bukti kepemilikan hak atas tanah terkuat di Indonesia, masih kalah dengan aturan adat. Contoh kasus, pembatalan sertifikat tanah bekas hak ulayat yang dinilai terdapat kesalahan pada obyek hak berdasarkan putusan Nomor: 30/G/2015/PTUN JPR oleh hakim Pengadilan Tata Usaha Negara Jayapura (Ivan \& Jamin., 2018).

Dilansir dari situs Jubi.co.id Majelis Rakyat Papua (MRP) menyebutkan kepemilikan tanah yang tidak disertai dengan dokumen surat pelepasan dari masyarakat adat pemilik hak ulayat adalah tidak sah. Hal ini berlaku, baik untuk kepemilikan tanah oleh perusahaan atau badan hukum, maupun kepemilikan tanah oleh orang perorangan (Wisanggeni, 2019). Menurut Ivan \& Jamin (2018) beberapa faktor yang menyebabkan terjadinya sengketa yang berujung pada perampasan atau menduduki secara paksa tanah bekas hak ulayat yang telah menjadi milik perorangan, dan telah bersertifikat, seperti ; adanya pihak keluarga atau masih dalam satu suku melakukan pengklaiman dengan alasan tidak mengetahui atau tidak dilibatkan pada saat tanah tersebut dilakukan peralihan atau pelepasan adat, karena letaknya strategis sehingga terkadang ada pihak ketiga sebagai provokator dengan menawarkan pembayaran yang lebih tinggi kepada masyarakat hukum adat sebagai pemilik sebelumnya, serta dilakukan penerbitan sertifikat dilakukan tanpa adanya pelepasan adat atas tanah tersebut.

Permasalahan mengenai adanya gugatan dan keberatan atas penjualan atau peralihan tanah ulayat tersebut, selanjutnya dijelaskan oleh seorang informan yang bertugas pada Kantor Pertanahan Kabupaten Jayapura berinisial IS, bahwa :

"Gugatan atau keberatan dari pihak lain adalah terkait dengan masalah penjualan hak ulayat tanah adat, ada orang yang sudah beli tanah, dia sudah bayar tetapi masih ada saja komplain ketika mau membangun atau mengurus sertifikat tanah. Komplain itu kadang datang dari dalam satu suku, marga, bahkan keluarga. Bapak kan juga sudah lama di Jayapura jadi pasti sudah tau, kondisi disini, kadang ini membuat kami pusing dan jengkel. Pemerintah Kadang sudah membeli/melepaskan tanah adat, tapi ada saja dikemudian hari dikomplain lagi, (Wawancara tanggal 21/10/2019).

Berdasarkan dari penjelasan tersebut, prosedur pelayanan yang menyangkut proses pengurusan pelayanan sertifikat tanah di Kabupaten Jayapura terkadang juga dipengaruhi oleh permasalahan pelepasan tanah adat. Selanjutnya, pembicaraan mengenai prosedur pelayanan sertifikat tanah pada kantor Pertanahan Kabupaten Jayapura telah dilaksanakan sesuai dengan standar pelayanan yang ada. Kendati demikian, masih adanya masyarakat memberi sejumlah uang ataupun melewati orang dalam yang mereka kenal. Akan tetapi dari sebagian informan dari aparat dan didukung oleh masyarakat, untuk dimensi responsiveness (daya tanggap) aparat kantor Pertanahan Kabupaten jayapura terkait dengan prosedur pelayanan sudah sesuai dengan standar pelayanan sebagaimana yang telah dipersyaratkan.

Jaminan (Assurance), pengetahuan dan keramahan petugas pada saat memberikan layanan serta kemampuan untuk menginspirasi, kepercayaan dan adanya kenyamanan bagi masyarakat atau pengguna layanan. Selanjutnya apabila dikaitkan dengan standar pelayanan dan pengaturan pertanahan, indikator ini berhubungan dengan kompetensi petugas pemberi 
layanan atau Sumber Daya Manusia (SDM) yang dimiliki oleh Kantor Pertanahan Kabupaten Jayapura yang menyangkut: a) Adanya pemahaman terhadap peraturan perundang-undangan seperti undang-undang pokok agraria, memahami standar pelayanan yang ada, memahami pengaturan pertanahan dan peraturan-peraturan lain yang memiliki kaitan dengan pertanahan, memahami petunjuk teknis dan petunjuk pelaksanaan, serta memahami akan peraturan internal yang ada pada kantor setempat. b) Kemampuan profesional yang dimiliki petugas baik itu di bidang teknis pertanahan, bidang pelayanan, serta bidang administrasi.

Sumber daya manusia yang memadai menjadi hal penting yang harus dimiliki suatu organisasi, termasuk yang berkaitan dengan pelayanan. Keputusan Menteri Pendayagunaan Aparatur Negara Nomor 63 tahun 2003 tentang pedoman Tatalaksana Pelayanan Umum, yaitu salah satu prinsip pelayanan umum adalah kedisiplinan, kesopanan dan keramahan. Pemberi pelayanan atau petugas pelayanan mesti mengedepankan sikap disiplin, sopan santun dan ramah serta ikhlas dalam memberikan pelayanan. Kurang bagusnya kualitas yang terjadi pada sumber daya manusia atau petugas pelayanan maka akan menghambat proses pelayanan itu sendiri. Menyangkut kompetensi berdasarkan tingkat pendidikan petugas pemberi layanan atau Sumber Daya Manusia yang dimiliki yang dapat mendukung proses pelayanan sertifikat tanah. Selanjutnya diuraikan pada masing tabel berikut:

Tabel 3. Persentase Aparatur Kantor Pertanahan Kab. Jayapura

Berdasarkan Tingkat Pendidikan

\begin{tabular}{clcc}
\hline No & \multicolumn{1}{c}{ Pendidikan } & Jumlah & $\%$ \\
\hline 1 & Magister (S-2) & 1 & 3,84 \\
2 & Sarjana (S-1) & 11 & 42,30 \\
3 & Diploma & 8 & 30,76 \\
4 & SLTA/sederajat & 6 & 23,10 \\
5 & SLTP/sederajat & - & - \\
6 & SD & - & - \\
& & 26 & 100 \\
\hline
\end{tabular}

Sumber: Kasubag.TU Kantor Pertanahan Kab. Jayapura

Pada tabel tersebut berdasarkan tingkat pendidikan dari total 26 orang pegawai yang bekerja pada Kantor Pertanahan Kabupaten Jayapura terlihat sebanyak 11 orang $(42,30 \%)$ sudah berpredikat sebagai sarjana Strata Satu (S-1), selanjutnya 8 orang $(30,76 \%)$ berpredikat Diploma. Sementara 6 orang $(23,76 \%)$ berpendidikan SLTA/sederajat dan 1 orang $(3,84 \%)$ berpendidikan Magister Strata Dua (S-2).

Manusia sebagai suatu insan dan sumber daya dituntut memiliki kemampuan yang sesuai dengan tugas dan fungsinya dalam mencapai tujuan organisasi. Meminjam pendapat Ilham et al., (2020) yang menyebutkan bahwa pembangunan sumber daya manusia yang mumpuni menjadi suatu keniscayaan dalam mensukseskan setiap program-program yang telah ditetapkan. Pada aspek kompetensi sumber daya manusia yang didalamnya memuat tentang pengetahuan dan keterampilan aparat dinilai cukup oleh kalangan internal Kantor Pertanahan Kabupaten Jayapura maupun sebagian masyarakat selaku pengguna yang beranggapan kualitas aparatur yang telah memadai. Kendati tidak semua petugas di lingkungan Kantor Pertanahan Kabupaten Jayapura mempunyai tingkat pendidikan yang cukup ataupun latar belakang pendidikan yang sesuai dengan pekerjaannya, tetapi pengetahuan mereka berkaitan dengan pengadministrasian dokumen pertanahan dinilai telah cukup memadai. Hal tersebut sejalan dengan pendapat salah seorang aparat Kantor Pertanahan Kabupaten Jayapura berinisial AD, yang mengatakan bahwa :

"Khusus untuk petugas kami yang melayani, saya kira tingkat pemahaman mereka terhadap peraturan perundang-undangan sesekali mereka mengikuti dasar-dasar 
pertanahan (diklat) maka kompetensi maupun kualitas SDM dirasa sudah cukup. Demikian juga kemampuan profesional, secara berkala Pegawai juga diikutkan diklat atau pelatihan-pelatihan" (Wawancara tanggal 28/10/2019)

Senada dengan pendapat tersebut, seorang informan lainnya berinisial BA turut mengemukakan mengenai tingkat pemahaman, pengalaman dan kualitas Sumber Daya Manusia (SDM) yang dimiliki aparatur pada Kantor Pertanahan Kabupaten Jayapura bahwa:

\begin{abstract}
"Pemahaman terhadap peraturan perundang-undangan, petugas pelayanan disini sudah memiliki pengalaman dan kualitas SDM yang baik karena sebagai petugas pelayan sudah dibekali pengetahuan mengenai peraturan-peraturan pertanahan. Seorang petugas pelayanan harus menguasai dasar-dasar tersebut agar dapat memberikan informasi yang akurat dan benar kepada pemohon apabila ditemukan beberapa masalah pertanahan baik saat proses pendaftaran maupun pengaduan atau sekedar memberikan informasi. Untuk kemampuan profesional saya kira petugas pelayanan secara berkala diikutkan pelatihan-pelatihan guna menunjang kemampuan profesional dan karier" (Wawancara tanggal 28/10/2019).
\end{abstract}

Kompetensi sumber daya manusia pada kantor pertanahan kabupaten Jayapura dari segi kualifikasi pendidikan yang sebagian besar berpendidikan formal sarjana strata satu maupun diploma, hanya sebagian kecil yang memiliki kualifikasi pendidikan secara teknis berhubungan dengan masalah pertanahan. Kendati demikian, Kantor Pertanahan Kabupaten Jayapura sendiri mempunyai kebijakan untuk melakukan pembinaan ataupun peningkatan kompetensi terhadap para petugas pelayanan dengan maksud agar para petugas dapat lebih mengerti ruang lingkup tugasnya dan hal-hal lain yang terkait seperti persyaratan yang dibutuhkan, prosedur, dan aspek-aspek teknis dasar lain di bidang pertanahan. Kapasitas sumber daya manusia menjadi faktor penting dalam suatu organisasi, sumber daya manusia merupakan human capital dan intellectual capital yang akan menentukan efektivitas dari sumberdaya lainnya yang dimiliki oleh suatu organisasi seperti modal/dana, peralatan, teknologi organisasi, struktur, dan lainlain. Sebaik apapun sistem yang telah disusun serta meski didukung sarana dan prasarana, tanpa adanya kemampuan atau kompetensi yang memadai untuk mengelolanya, maka berbagai kelengkapan tersebut tidak akan berarti banyak bagi keberadaan organisasi.

Dengan sumber daya manusia pula, sistem sarana dan prasarana yang ada dalam organisasi dapat terus disempurnakan, sesuai dengan perkembangan kebutuhan bagi percepatan penyelesaian tugas. Oleh karena itu, suatu organisasi harus memiliki sumberdaya manusia yang mempunyai kompetensi dan sesuai dengan kebutuhan organisasi tersebut. Seperti dikatakan oleh Sedarmayanti, (2009) bahwa kompetensi Sumber Daya Manusia merupakan karakteristik sikap dan perilaku yang efektif yang akan menentukan kinerja unggul dalam pekerjaan. Bertolak dari pendapat tersebut maka demikian pula dengan kompetensi Sumber Daya Manusia (SDM) aparatur akan berpengaruh dan menentukan efektivitas organisasi termasuk pada Kantor Pertanahan Kabupaten Jayapura dalam menyelenggarakan tugas dan fungsinya. Salah satu tugas dan fungsi pokok dari organisasi pemerintah dengan menyelenggarakan pelayanan public yang berpihak kepada masyarakat atau pengguna layanan.

\title{
V. KESIMPULAN
}

Pemberian pelayanan pengurusan sertifikat tanah pada Kantor Pertanahan Kabupaten Jayapura belum didukung dengan sarana dan prasarana yang memadai sesuai dengan standar pelayanan dan pengaturan yang telah dipersyaratkan, seperti; perlengkapan keamanan, kotak pengaduan, bagan alir/panel informasi yang belum tersedia. Untuk standardisasi loket 
pelayanan menyangkut desain dan tata letak ruang pelayanan juga belum maksimal karena pada kenyataannya ruangan yang ada masih sangat sempit (tangibles).

Proses pengaduan masyarakat atau pun surat masuk telah dilaksanakan sesuai mekanisme yang ada. Kendati demikian permasalahan yang sering terjadi adalah transparansi informasi mengenai perkembangan pengaduan masyarakat dan tahap penyelesaian pengaduan. Proses pemberitahuan kepada pengadu rata-rata telah direspon dalam 5 (lima) hari kerja tetapi penyelesaian pengaduan kadang memakan waktu lama sebab banyaknya pengaduan dan sengketa tanah dalam antrian untuk dilakukan penyelesaian. Banyaknya pengaduan masyarakat mengindikasikan bahwa Kantor Pertanahan Kabupaten Jayapura belum memberikan pelayanan secara terbuka, terbukti masih banyak masyarakat yang menanyakan prosedur pelayanan pengaduan yang menurut mereka masih belum jelas dan kurang dapat dimengerti (empathy).

Tahapan pengurusan hingga penerbitan sertifikat tanah pada Kantor Pertanahan Kabupaten Jayapura telah berjalan sesuai dengan prosedur yang dipersyaratkan dalam standar pelayanan dan pengaturan pertanahan tetapi belum sepenuhnya dapat berjalan dengan baik. Khususnya penyelesaian sertifikat tanah yang memakan waktu cukup lama dan berlarut-larut, bahkan tahunan (1-3 tahun) yang melampaui waktu sebagaimana dipersyaratkan (98 hari). Salah satu faktor penyebab keterlambatan tersebut karena permasalahan status kepemilikan tanah ulayat atau tanah bersama warga masyarakat hukum adat di Papua. Khususnya biaya pendaftaran tanah pertama kali dilaksanakan melalui tiga item pembayaran yakni; biaya pendaftaran pertama kali (Rp50.000,00), biaya panitia dan biaya pengukuran yang besarnya tergantung pada luas tanah yang dimohon dan penggunaan tanah (pertanian/non pertanian), selain biaya tersebut kepada pemohon juga dibebankan biaya operasional (reliability).

Prosedur pelayanan telah dilaksanakan dan diterapkan dengan baik pada Kantor Pertanahan Kabupaten Jayapura dengan berdasarkan pada flowchart atau alur loket sebagaimana diatur dalam Perkaban Nomor 1 Tahun 2010. Baik dokumen fisik maupun aplikasi (khususnya pendaftaran tanah pertama kali) semua proses telah berjalan sesuai peraturan yang ada. Permohonan baru akan diproses apabila semua kelengkapan dokumen telah terpenuhi (responsiveness).

Kompetensi pemberi layanan atau sumber daya manusia yang memuat pengetahuan dan keterampilan mengenai pengadministrasian dokumen pertanahan dinilai telah cukup memadai, meskipun tidak semua petugas yang ada pada Kantor Pertanahan Kabupaten Jayapura mempunyai tingkat pendidikan yang cukup dengan latar belakang pendidikan yang sesuai dengan pekerjaannya. Adapun upaya yang dilakukan dalam meningkatkan kompetensi dengan secara berkala mengikutkan petugas dalam kegiatan pendidikan dan pelatihan (diklat) guna meningkatkan profesionalitas dan kemampuan petugas mengenai dasar-dasar pertanahan (assurance).

Sebagai rekomendasi, Pertama perlu ditingkatkan rasa empati oleh aparat yang bertugas langsung dalam memberikan pelayanan sertifikat tanah agar mereka tanggap dalam menerima keluhan dari masyarakat. Kedua, pengawasan dan monitoring oleh pimpinan Kantor Pertanahan terhadap penyelenggara pelayanan perlu ditingkatkan, tetapi dalam pelaksanaannya sulit diterapkan karena kurangnya pengawasan dari pimpinan. Ketiga, proses pengurusan sertifikat tanah di Kabupaten Jayapura terkadang dihadapkan dengan adanya komplain atas status kepemilikan tanah ulayat atau tanah bersama warga masyarakat hukum adat meskipun sebelumnya telah dilakukan pelepasan adat. Penting adanya regulasi yang akan menjadi grand design hukum tanah di Papua.

\section{REFERENSI}

Abidin, T.Z., Mustam, M., Lituhayu, D., \& Warsono, H. (2016). Analisis Kualitas Pelayanan Pembuatan Sertifikat Tanah Di Kantor Pertanahan Kabupaten Boyolali. Journal of Public Policy and Management Review, 5(3). https://doi.org/10.14710/jppmr.v5i3.12553 
Affandi, H., Zaki, M., \& Azmeri, M. (2017). Pengaruh Kualitas Pelayanan Terhadap Kepuasan Pelanggan Pada Perusahaan Daerah Air Minum (Pdam) Tirta Mon Pase Kabupaten Aceh Utara. Jurnal Teknik Sipil Universitas Syiah Kuala, 6(3), 297-308. http://jurnal.unsyiah.ac.id/JTS/article/view/9845.

Anggiawan, D. D., Pandie, E. S. Y., \& Boru, M. (2018). Sistem Informasi Pelayanan Publik Kelurahan Bakunase Kota Kupang Untuk Peningkatan Kualitas Pelayanan Berbasis Web. J-Icon, 6(2), 8-13. https://doi.org/10.35508/jicon.v6i2.509

Benu, V. W. (2020). Membaca Hak Publik di Kantor Pertanahan. (Ombudsman Online, 09 Mei 2020) Retrieved from https://ombudsman.go.id/artikel/r/artikel--membaca-hak-publik-dikantor-pertanahan diakses tanggal: 19 September 2020.

G, Aryo. W. (2019). Kepemilikan Tanah Tanpa Surat Pelepasan Adat Tidak Sah. Jubi Online, 18 Juni 2019) Retrieved from https://jubi.co.id/kepemilihan-tanah-tanpa-surat-pelepasanadat-tidak-sah/ diakses tanggal: 20 September 2020.

Hamzah, A. (2020). Metode Penelitian Kepustakaan, Kajian Filosofis, Teoritis, Aplikasi, Proses, dan Hasil Penelitian (Edisi Revisi). F. R. Akbar(Ed.). Malang: Literasi Nusantara Abadi.

Hayat., Nuh. M., Fanani A. F., Kuntariningsih A., Hamid A., Wati Y.P., Indriyati., Jaunuri., Masrun M.F., Dasril M., Akibu R.S., Hajar S., Tressa R., Yunus., \& Iqbal M.M . (2018). Reformasi Kebijakan Publik, Perspektif Makro dan Mikro. Hayat (Ed.), Jakarta : PRENADAMEDIA GROUP (Divisi Kencana).

Hidayati, N. (2018). Upaya Peningkatan Kualitas Pelayanan Aparat Desa Kepada Publik. Istithmar: Jurnal Studi Ekonomi Syariah, 2(1). https://doi.org/10.1017/CBO9781107415324.004

Ilham, I., Muttaqin M. Z., \& Idris U. (2020). Pengembangan Bumkam Berbasis Potensi Lokal Di Kawasan Perbatasan Indonesia-Papua New Guinea. Communnity Development Journal, 1(2), 104-109. https://doi.org/10.31004/cdj.v1i2.722.

Ivan, Epifanius., Jamin M. (2018). Pembatalan Sertifikat Hak Milik Atas Tanah Bekas Hak Ulayat Oleh Hakim Di Pengadilan Tata Usaha Negara Jayapura. Jurnal Repertorium, 5(2). https://jurnal.uns.ac.id/repertorium/article/view/17706.

Jawahir, M., Soaedy, S., \& Rozikin, M. (2015). Perspektif Administrasi Publik (Studi Pada Kantor Badan Pertanahan Nasional Kota Batu). Jurnal Administrasi Publik, 3(12),20842088. http://administrasipublik.studentjournal.ub.ac.id/index.php/jap/article/view/1063.

Jufri, H. (2019). Birokrasi dan Upaya Meningkatkan Pelayanan Publik. (Kemenag Online, 02 September 2019) Retrieved from https://bengkulu.kemenag.go.id/opini/314-birokrasidan-upaya-meningkatkan-pelayanan-publik diakses tanggal: 16 Oktober 2020.

Keban, Y. T. (2008). Enam Dimensi Strategis Administrasi Publik: Konsep, Teori, dan Isu. Yogyakarta: Gava Media.

Kirihio, M. P. (2019). Ombudsman RI Perwakilan Provinsi Papua dan Tim Keasistenan Substansi IV Ombudsman RI Gelar Laporan bersama Kanwil ATR BPN Provinsi Papua. (Ombudsman Online, 08 Maret 2019) Retrieved from https://ombudsman.go.id/artikel/r/artikel--ombudsman-ri-perwakilan-provinsi-papuadan-tim-keasistenan-substansi-iv-ombudsman-ri-gelar-laporan-bersama-kanwil-atr-bpnprovinsi-papua diakses tanggal: 18 September 2020.

Marbun, J. (2014). DPRD: Masyarakat Kurang Puas dengan Pelayanan BPN. (Republika Online, $\quad 04 \quad$ April 2014) $\quad$ Retrieved from https://republika.co.id/berita/nasional/daerah/14/04/04/n3h4i9-dprd-masyarakat-kurangpuas-dengan-pelayanan-bpn diakses tanggal: 16 Oktober 2020.

Mardiana, T. (2020). Menyingkirkan Budaya 'Enggan' Melapor di Masyarakat. (Ombudsman Online, 12 Februari 2020) Retrieved from https://ombudsman.go.id/artikel/r/artikel-menyingkirkan-budaya-enggan-melapor-di-masyarakat diakses tanggal: 16 Oktober 
2020.

Miles, Mathew B., \& Huberman A. Michael . (1992). Analisis Data Kualitatif; Buku Sumber Tentang Metode-metode Baru. Jakarta : Universitas Indonesia Press.

Moenir, H. A. S. (1992). Manajemen Pelayanan Umum di Indonesia. Jakarta : Bumi Aksara.

Moleong, L. J. (2017). Metodologi Penelitian Kualitatif (Edisi Revisi). Bandung : Remaja Rosda Karya.

Najmi, F. (2017). Pengaruh Keandalan Dan Prosedur Pelayanan Terhadap Kepuasan Masyarakat Pada Kantor Urusan Agama Liang Anggang Kota Banjarbaru. Jurnal Ilmiah Ekonomi Bisnis, 3(2), 251-263. https://doi.org/10.35972/jieb.v3i2.102

Ningtyas, T. (2017). New Public Service: Pelayan Publik Berbasis Humanistik Untuk Kesuksesan Reformasi Birokrasi. Jurnal Ilmiah Manajemen Publik Dan Kebijakan Sosial, 1(1). https://doi.org/http://dx.doi.org/10.25139/jmnegara.v1i1.283

Nurdin. (2017). Implementasi Kebijakan Program Layanan Rakyat Untuk Sertipikasi Tanah (Larasita) Di Kantor Pertanahan Kabupaten Donggala. Jurnal Katalogis, 5(5), 82-90. http://jurnal.untad.ac.id/jurnal/index.php/Katalogis/article/view/9557.

Panjaitan, J. E., \& Yuliati, A. L. (2016). Pengaruh Kualitas Pelayanan Terhadap Kepuasan Pelanggan Pada JNE Cabang Bandung. DeReMa (Development Research of Management): Jurnal Manajemen, 11(2), 265-289. https://doi.org/10.19166/derema.v11i2.197

Parasuraman, A., Zeithaml, V. A., \& Berry, L. L. (1985). A Conceptual Model Service Its Quality and Implications for Future Research. Research Paper, 49(4), 41-50. https://doi.org/10.1016/S0148-2963(99)00084-3.

Pasolong, H. (2017). Teori Administrasi Publik (8th ed.). Bandung : Alfabeta.

Prasojo, E. \& M. (2017). Kualitas pelayanan sertifikat tanah di kantor pertanahan kota administrasi jakarta selatan. SWATANTRA, 15(1), 34-45. https://jurnal.umj.ac.id/index.php/SWATANTRA/article/view/2582

Puung, Florensina K., Fudholi A ., \& Dharmmesta B. S. (2014). Analisis Pengaruh Kualitas Pelayanan Pada Kepuasan Dan Loyalitas Pelanggan di Salon dan Spa. Jurnal Manajemen dan Pelayanan Farmasi, 4(2), 105-110. https://doi.org/https://doi.org/10.22146/jmpf.2742146/jmpf.274

Rudiyanto, A., Oktorialdi, Hussein, U. M., Tambunan, R., Apriyana, N., Amalia, M., Yulianti, S., Hernydawaty, Aswicaksana, Noor, R., Ciptadi, E. Y., Khalik, I., Widayati, L., Sesotyaningtyas, M., Pranadi, R., Krisnawati, S., Saryanto, C., \& Supriatna, U. (2016). Kajian Persiapan Perubahan Sistem Pendaftaran Tanah Publikasi Positif di Indonesia. Jakarta : Direktorat Tata Ruang dan Pertanahan Kementerian Perencanaan Pembangunan Nasional-Bappenas.

Saputra, M. E. (2017). Analisis pelaksanaan layanan rakyat untuk sertifikat tanah (larasita) di kantor pertanahan kota samarinda. Jurnal Administrative Reform, 5(2), 93-102. http://dx.doi.org/10.30872/jar.v5i2.841

Sedarmayanti. (2009). Birokrasi dan Manajemen Pegawai Negeri Sipil. Bandung: Rafika ADITAMA.

Sitorus, M. (2009). Pengaruh Reliability, Responsiveness, Assurance, Empathy Dan Tangibles Terhadap Kualitas Pelayanan Publik (Studi Kasus Kantor Pelayanan Terpadu Kota Dumai). Jurnal Borneo Administrator, 5(1), 1-15. https://doi.org/https://doi.org/https://doi.org/10.24258/jba.v5i1.40

Styawan, S. (2012). Penanganan Pengaduan (Complaint Handling) Dalam Pelayanan Publik (Studi Tentang Transparansi, Responsivitas, Dan Akuntabilitas Dalam Penanganan Pengaduan di Kantor Pertanahan Kota Surabaya II).Jurnal Kebijakan dan Manajemen Publik, 4(4). http://www.journal.unair.ac.id/filerPDF/kmpbc2857774dfull.pdf

Suaib, M. R. (2017). Kebijakan Pelayanan Pengurusan Sertifikat Tanah Adat Di Kantor 
Pertanahan Kota Sorong. Jurnal Noken: Ilmu-Ilmu Sosial, 3(1), 1-10. https://doi.org/10.33506/jn.v3i1.59

Sulistyawati, Ni Made A., Seminari N. K. (2015). Pengaruh Kualitas Pelayanan Terhadap Kepuasan Pelanggan Restoran Indus Ubud Gianyar. E- Jurnal Manajemen Unud, 4(8), 2318-2332. https://ojs.unud.ac.id/index.php/Manajemen/article/view/12882

Suparman, N. (2017). Kualitas Pelayanan Izin Mendirikan Bangunan (IMB) Pada Badan Pelayanan Perizinan Terpadu dan Penanaman Modal (BPPTPM) Kabupaten Cianjur Provinsi Jawa Barat. Jurnal Borneo Administrator, 13(1), 41-56. https://doi.org/10.24258/jba.v13i1.274

Tamimi, Zindar. (2015). Inovasi Manajemen Pelayanan Publik Tim Emergency Service Kabupaten Bantaeng. $\quad$ POLITIKA, 6(1), 141-158. https://doi.org/10.14710/politika.6.1.2015.141-158

Tianlajanu, A., Padmanaba A. A., \& Ayuningtyas. D. N. (2015). Pendaftaran Tanah Pertama Kali Melalui Program Larasita Di Kantor Pertanahan Kota Bogor. Majalah Ilmiah Gema, 27 (49), 1543-1554 : GEMA, TH. XXVII/49/AGUSTUS 2014 - JANUARI 2015

Tjiptono, F., \& Chandra. G. (2016). Service, Quality dan Satisfaction Edisi 4. Yogyakarta : Penerbit ANDI.

Usulu, E. M. (2019). Efektifitas Pelayanan Pembuatan Sertifikat Tanah Badan Pertanahan Nasional Kota Jayapura. Jurnal Ilmu Administrasi Dan Ilmu Pemerintahan, 3(1), 187194. http://jurnal.uniyap.ac.id/jurnal/index.php/jurnalfisip/article/view/486 